\title{
The Larval Stages of Trivia europea.
}

\author{
By \\ Marie V. Lebour, D.Sc., \\ Naturalist at the Plymouth Laboratory. \\ With One Text-figure and Plates I-IV.
}

IN 1926 Pelseneer discovered the eggs of Trivia europea on the French coast. These he found were laid in capsules embedded in the compound ascidian Polyclinum luteum, the mollusc biting a hole and laying its eggs in a vase-like capsule completely enveloped in the ascidian except for the wide lip of the vase which projects freely and can be easily seen with the naked eye (Pelseneer, 1926, Figs. 11-12). He also hatched some larvæ from these eggs which were very interesting, as they possessed an accessory shell somewhat similar in shape to the Echinospira of Lamellaria perspicua. He did not obtain the eggs directly from the Trivia and was not able to keep the larvæ alive more than a few days. In his paper he expresses the hope that some worker will confirm his observations experimentally. This I am now able to do, having procured the eggs actually laid by the Trivia, hatched them out and kept them alive for more than a week, afterwards collecting the larvæ from the plankton from stages which exactly corresponded with those from the egg up to late stages which metamorphosed into young Trivia, and young stages of Trivia feeding on compound ascidians which corresponded with the metamorphosed forms.

Trivia europea is common at Plymouth between tide-marks and in a few fathoms of water; occasionally further out in deeper water. Records are available from the shore to the region beyond the Eddystone.

In order to obtain the eggs several adults were collected and placed in a plunger-jar. They were given various compound ascidians to eat and they ate largely of Diplosoma listerianum var. gelatinosum $(=$ Leptoclinum gelatinosum). This ascidian grows well on the glass sides of the Laboratory tanks and is therefore a very convenient food. The Trivia also ate various forms of Botryllus, Botrylloides, and Trididemnum tenerum. Although placed in the plunger-jar in winter and spring and eating well they laid no eggs until June. On June 1st, 1931, several egg capsules were laid in an orange mass of Botryllus placed in the jar the night before (Text-Figure 1). These egg capsules were exactly similar to those found 
by Pelseneer. Unfortunately the Botryllus died and also the eggs. On June 5th another capsule was laid in a small aerated glass vessel in which two Trivia and an orange Botryllus had been placed overnight. This Botryllus and eggs also died. During the night of June 14/15th two capsules were laid in a new lot of Botryllus in the plunger-jar. This was pale yellow and only a small piece growing on an old stalk of Eunicella. It was still living on June 16th, and between June 16th and 23rd there were six capsules in this piece of Botryllus. Some of these died, but on June 29th two capsules contained active embryos, probably those laid on the $14 / 15$ th. The Botryllus with the two capsules containing active embryos was then placed in a fresh plunger-jar and the young from one

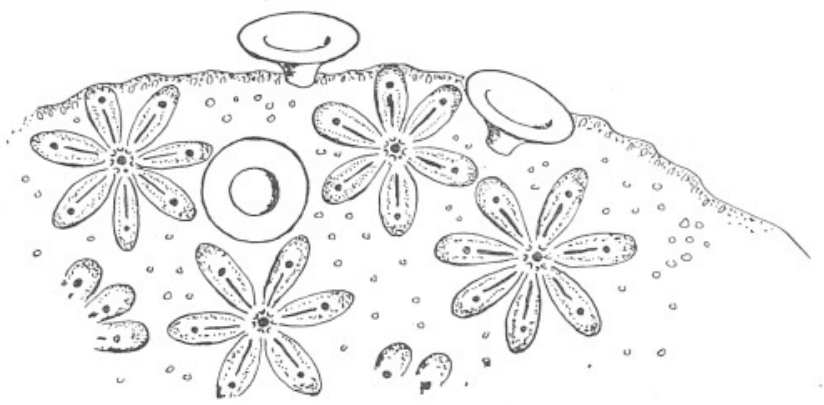

Texr-Fig. 1.-Egg capsules of Trivia in Botryllus.

capsule hatched on July 6th, those from the other capsule died. On June 29th two egg capsules were laid in Trididemnum tenerum, but neither the ascidian nor the eggs lived. Ascidians of an orange or yellow colour were always chosen for the eggs, probably because the eggs were themselves a bright orange and were thus protected. The larvæ from the capsules in Botryllus seemed to have hatched prematurely, for they still retained a large amount of yolk, the accessory shell was not completely formed and the true shell only indicated. The velum was present, however, and the larvæ were swimming about. In a few days they resembled the newly hatched young figured by Pelseneer (op. cit., Fig. 16).

On the whole the Trivia seemed to prefer Diplosoma to eat and Botryllus to lay eggs in. They are usually found in the neighbourhood of Botryllus when collected between tide-marks, or they may be on Diplosoma. It is easy to watch them eating the ascidians with the long proboscis outstretched to its greatest length and the food rapidly entering the mouth (Plate IV, Figs. 5-6).

Although some of the Trivia have been kept for several months no more eggs have been laid since June. They must, however, breed in most months, for in any month of the year the larvæ both young and old may 
be found in the plankton, perhaps more plentifully in spring and summer. They are quite common and usually to be found in the tow-nets from inside the Sound or a little way beyond, more rarely from deeper water.

The egg capsules measure about $4.8 \mathrm{~mm}$. in height and contain several hundred eggs, each when newly hatched measuring $0 \cdot 16 \mathrm{~mm}$. across (Plate I, Fig. 1). The eggs are a bright orange, the capsules colourless and transparent, very thin where they are imbedded in the ascidian, but the lip is thickened where it projects and the eggs are covered over securely. The embryos when hatching break through the mouth-covering and swim away. Those hatched in the plunger-jar had a small bi-lobed velum, eyes on rudimentary tentacles with a projecting lobe in front, conspicuous larval kidneys (so called) just behind the velum, a mouth ventrally, otoliths at the base of the foot which is short and already provided with an operculum, the accessory shell forming and the true shell barely perceptible. Nearly all the body is full of orange yolk (Plate II, Fig. 1). The accessory shell measures about $0.18 \mathrm{~mm}$. across. The unnatural condition may account for them being hatched prematurely. The plungerjar in which the eggs were laid and hatched were on a Laboratory table under ordinary Laboratory conditions and temperature and the water was not changed at all. A pure culture of Nitzschia was given to the larvæ to eat and those of nearly a week old seemed to be feeding, but they did not live more than ten days.

The yolk disappears when the shell is about $0 \cdot 24 \mathrm{~mm}$. across, and the stomach, œsophagus, and intestine are developed. The animal is very dark, the liver being dark yellowish brown, the stomach, intestine, and œsophagus a dark purplish brown. These colours are retained throughout the larval life and are very characteristic (Plate I, Figs. 2-20 ; Plate II, Figs. 2-5). Later the outer margin of the velum has a very thin brown border. At $0.36 \mathrm{~mm}$. across the accessory shell the true shell measures $0.16 \mathrm{~mm}$. across. The velum is about $0.4 \mathrm{~mm}$. across and very slightly indented at the centre of each side. The so called larval kidneys are still recognisable. At this stage the larvæ may be found in the plankton and are exactly like those which were reared from the egg (Plate I, Figs. 3, 4; Plate II, Fig. 4). They agree very well with Pelseneer's newly hatched larvæ. From this stage onwards larvæ of all sizes may be found in the plankton. The so-called larval kidneys now disappear and the true kidneys are formed, but the alimentary canal changes little. The velum grows large, the faint brown border appears in the later stages (Plate I, Figs. 17, 20), the front lobes are rather longer than the hind lobes. The velum has the usual structure, having a ridge with long cilia on the margin and an inner ridge of smaller cilia below, the two forming a groove to the mouth. The foot develops two large lateral lobes which help to support a very large spiral operculum (Plate III, Figs. 1, 2). When the accessory 
shell is about $1.25 \mathrm{~mm}$. across there is an anterior lobe to the foot which hides the mouth. The foot in the larvæ usually has scattered brown pigment on the sole. The tentacles are long and the mantle begins to project from the true shell. A gill is beginning to form at this stage (Plate I, Figs. 18-20). The accessory shell is perfectly clear and unsculptured, the only structure being a few lines of growth. The outer lip projects slightly. The true shell lies within the accessory shell and its whorls correspond in those of the accessory shell. This is an important difference which distinguishes it at once from the Echinospira of Lamellaria perspicua in which the whorls of the accessory (Echinospira) shell do not correspond with those of the true shell, the latter being placed excentrically. Another Echinospira occurring at Plymouth, probably belonging to Velutina, is like Lamellaria in this respect (Plate III, Figs. 8-9 ; Plate IV, Figs. 1, 2, 3). This unidentified Echinospira in its younger stages is like Trivia in many ways, including the shape of the velum. These facts emphasise the probable relationship of Trivia and the Lamellariidæ which has been suggested by Pelseneer (op. cit.).

At about 1.25 to $1.4 \mathrm{~mm}$. across the accessory shell Trivia begins to metamorphose. This is done in quite a different way from Lamellaria, for whereas in Lamellaria the Echinospira shell is cast off as a crumpled skin, the mantle immediately surrounding and covering the true shell, in Trivia the accessory shell remains and the mantle surrounds and covers it (Plate III, Figs. 3-4). It is then probably dissolved. The foot loses its lateral lobes and operculum, a short siphon is formed and the animal crawls (Plate III, Figs. 5-7). As the mantle comes up round the shell, small protuberances with stalks embedded in the mantle are conspicuous. These look like soft nails with yellow heads placed irregularly round the base of the mantle and become the mantle-papillæ of the adult (Plate III, Figs. 5, 7 and 13). The shell soon becomes oval in shape and the body whorl elongated along the main axis. It is pearly white and perfectly smooth (Plate III, Figs. 10 and 11). This young shell is well known. Vayssière (1923) gives a figure of it. The siphon elongates and the mantle gradually covers the shell when the animal is active, but the whole animal may be completely withdrawn into the shell. Young individuals can be found crawling on compound ascidians in the Sound (Plate III, Figs. 1213). The body and mantle can be variously coloured, the prevailing colours being cream, yellow, orange or brownish purple with small or large spots. Pale yellow with purple spots is a very usual combination, or brownish with orange spots, or the whole may be bright orange with various dark spots. The papillæ which are arranged chiefly on the sides of the lower surface of the mantle are yellow or orange, and there may be yellow or orange spots on the tentacles.

In the plunger-jars the larvæ from the plankton grow quickly and also 
grow well after metamorphosis. It seems probably that it takes about a month or five weeks under Laboratory conditions from hatching to metamorphosis, a few weeks sufficing for the animal to obtain the elongated adolescent shell covered by the mantle. The adults live well in a plunger-jar. Some have been in the Laboratory for nine months with only two changes of water and are still alive (September).

\section{LITERATURE.}

Pelseneer, P. 1926. Note d'embryologie malacologique. Ponte et développement de Cypraca europea, Trifora perversa et Lucina lactea. Bull. Biol. de la France et de la Belgique, LX, 1, pp. 88-112.

VAYssière, A. 1923. Recherches zoologiques et anatomiques sur les mollusques de la famille des Cypræidés. Ann. du Musée Nat. de Marseille. Zool., XVIII, pp. 1-1132. 


\section{PLATE I. (Scale A.)}

FIG. 1.-Egg capsule from Botryllus, $4 \cdot 8 \mathrm{~mm}$. high.

Fig. 2.-Young from egg, 5 days old, $0 \cdot 35 \mathrm{~mm}$. across shell.

FIG. 3.-Young from egg, 7 days old, $0 \cdot 40 \mathrm{~mm}$. across shell.

Figs. 4-20.-Young from plankton.

Fig. 4.-0.4 mm. across shell.

Figs. 5, 6, 7.-0.48 mm. across shell.

Figs. 8, 9.-0.56 mm. across shell.

Figs. 10, 11. $-0.64 \mathrm{~mm}$. across shell.

FIG. 12. $-0.70 \mathrm{~mm}$. across shell.

Figs. 13, 14. $-0.80 \mathrm{~mm}$. across shell.

Figs. 15, 16, 17. $-0.96 \mathrm{~mm}$. across shell.

Figs. 18, 19, 20.-1.25 mm. across shell. 
PLATE I.
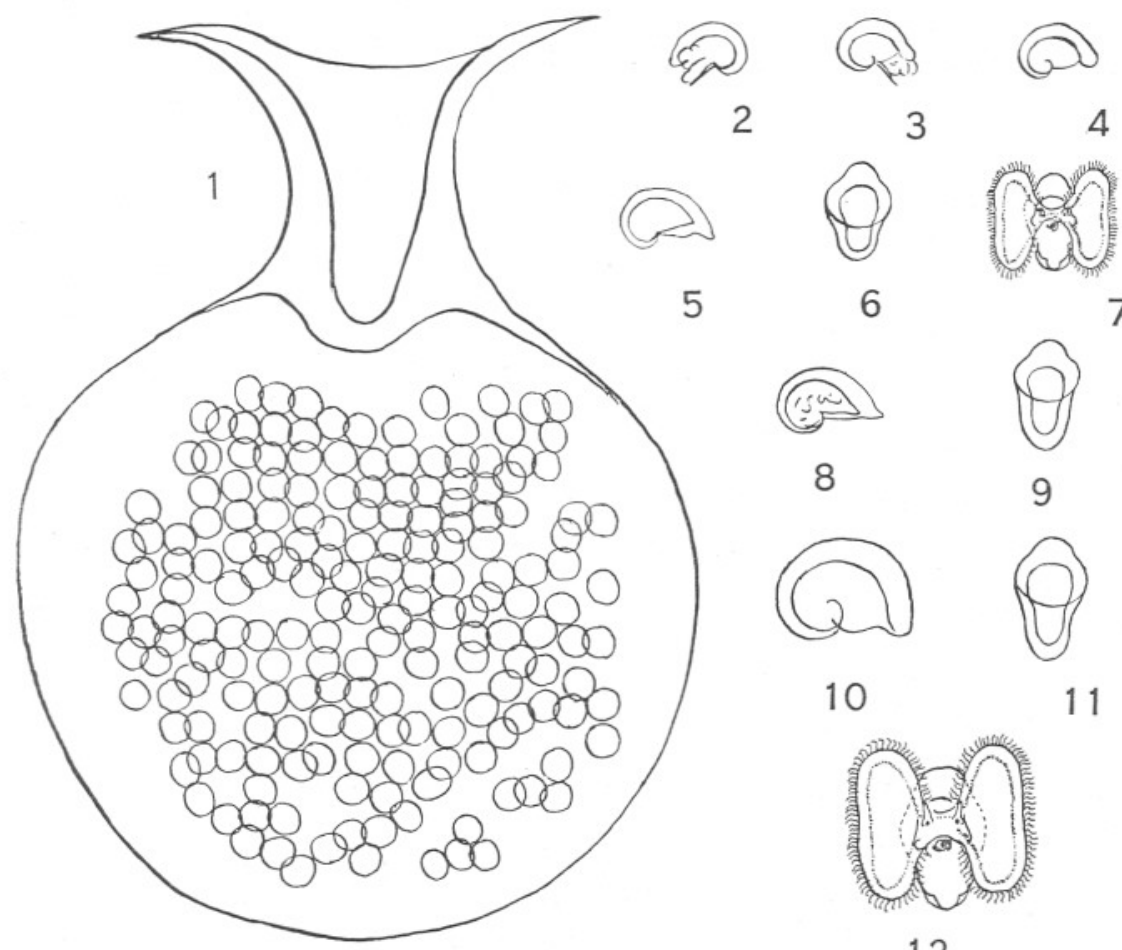

2

6 7

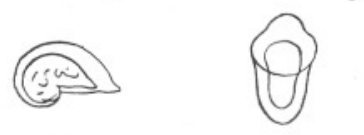

8

9
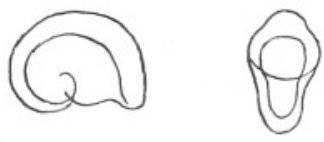

10

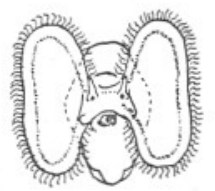

12
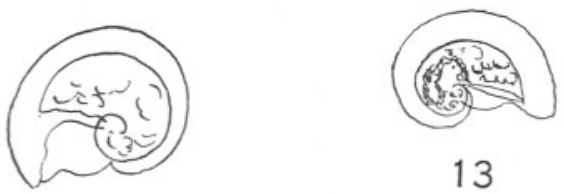

13

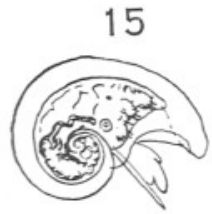

16
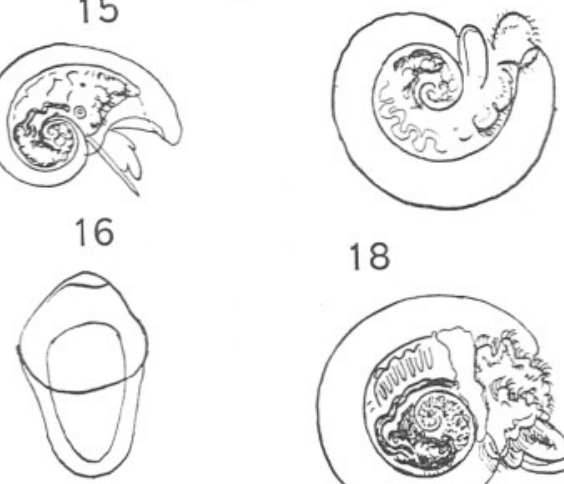

18

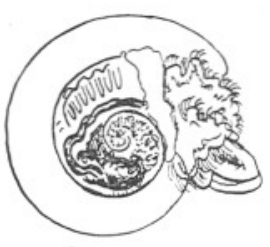

19

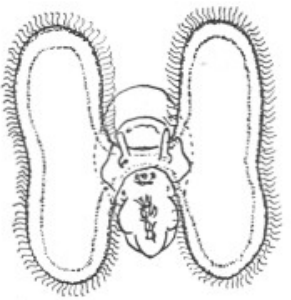

14

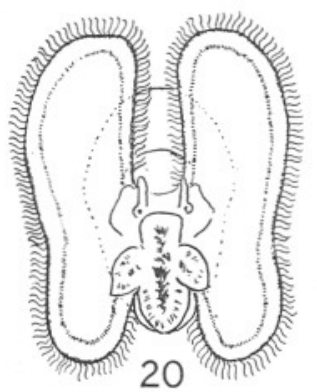

17

Eggs and Larvæ of Trivia europea.

NEW SERIES.-VOL. XVII. NO. 3. OCTOBER, 1931. 
PLATE II. (Scale B, six times the size of A.)

FIG. 1.-Young newly hatched from egg, $0 \cdot 18 \mathrm{~mm}$. across shell. FIG. 2.-Young from egg, $0.24 \mathrm{~mm}$. across shell.

FIG. 3.-Young from egg, 5 days old, $0 \cdot 35 \mathrm{~mm}$. across shell. FIG. 4.-Young from egg, 7 days old, $0 \cdot 36 \mathrm{~mm}$. across shell. FIG. 5.-Young from plankton, $0 \cdot 64 \mathrm{~mm}$. across shell. 
PLATE II.
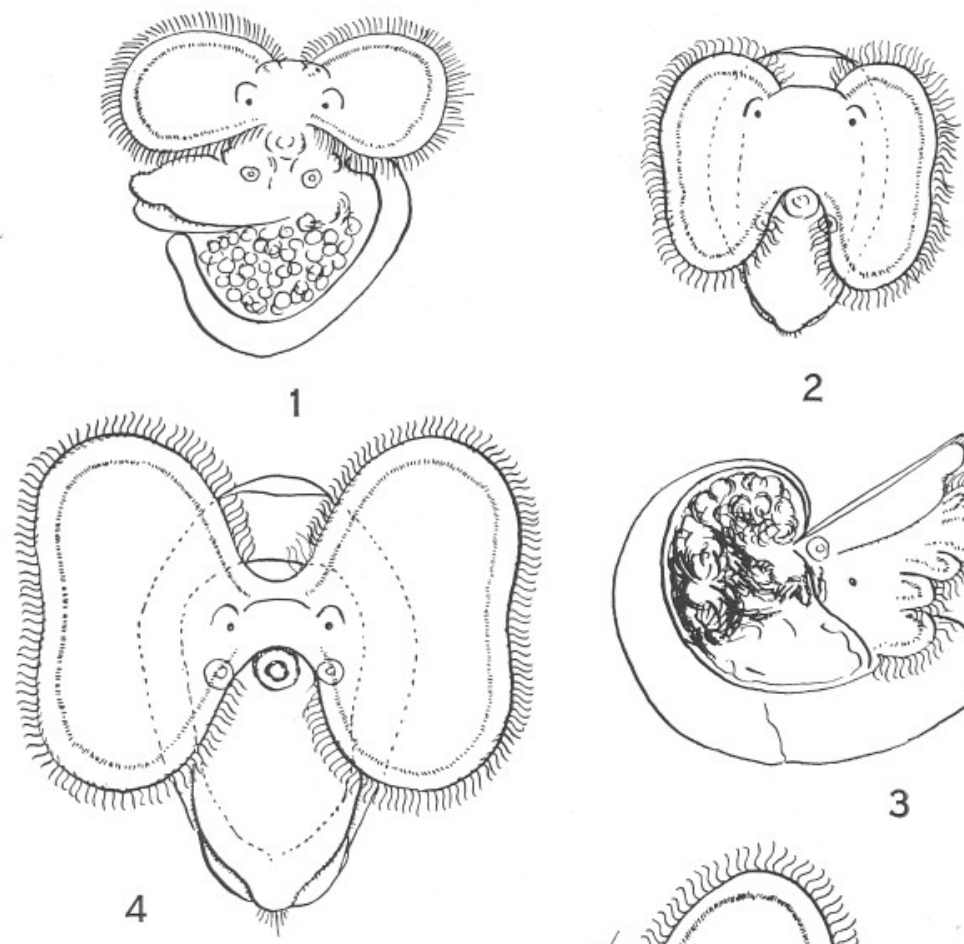

2
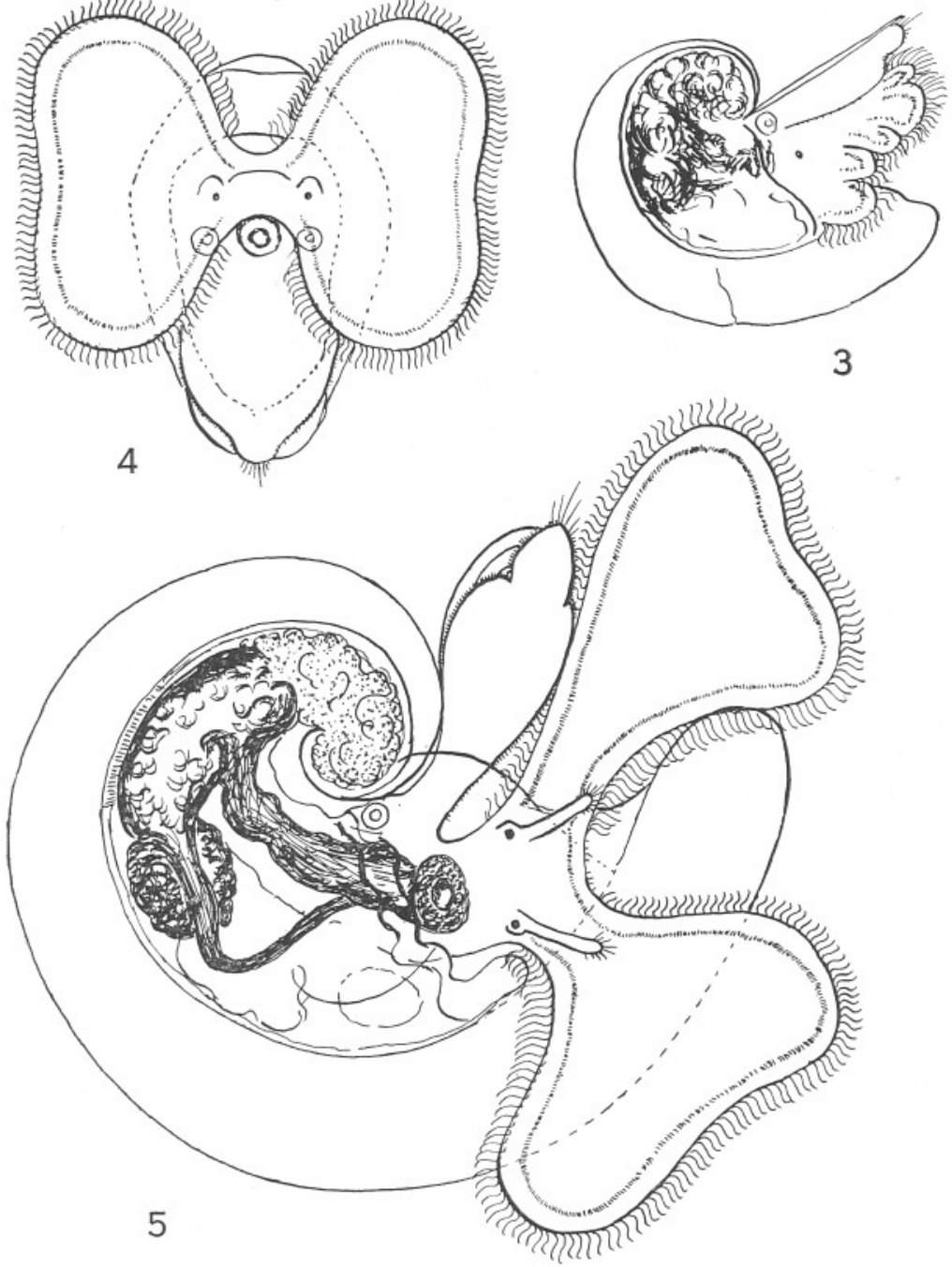

Larvæ of Trivia europea. 
PLATE III. (1-4 and 8,9 , Scale A, the others on a smaller scale.)

Fra. 1.-Operculum of young, 0.64 mm. across shell.

FIG. 2.-Operculum of young, ready to metamorphose.

Fig. 3.-Young from plankton, $1.44 \mathrm{~mm}$. across shell.

FIG. 4.-The same metamorphosing.

Figs. 5-7.-The same after metamorphosis.

Figs. 8, 9.-Empty shell, $1.4 \mathrm{~mm}$. across.

Figs. 10, 11.-Shell of older individual grown from young in plunger-jar, $4 \mathrm{~mm}$. long. Figs. 12, 13.-Young found erawling on Diplosoma, from Sound, shell 3.5 mm. long. 


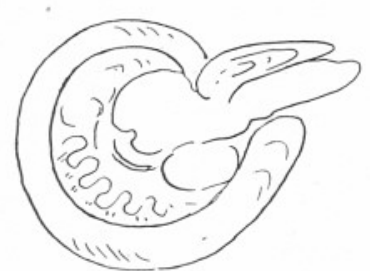

3

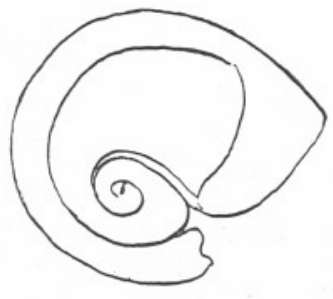

8

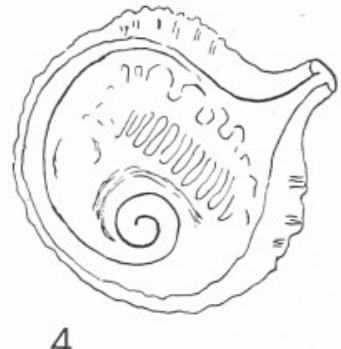

4

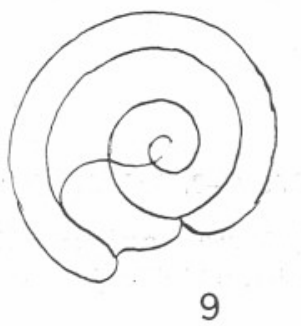

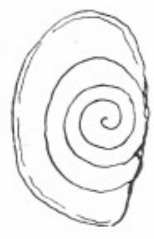

2

(9) 1
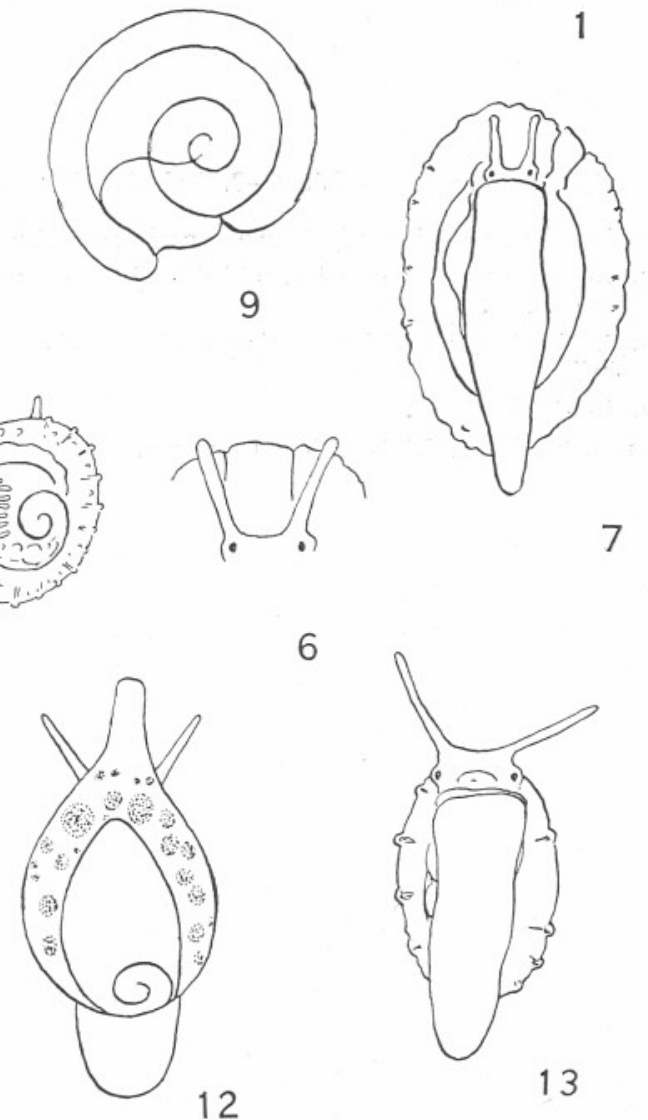

12
5

6
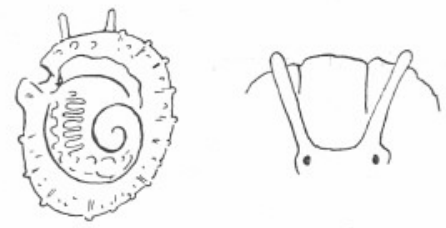

13
11

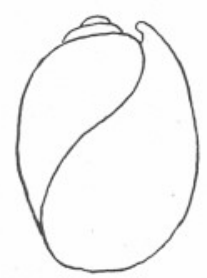

Larvæ and young of Trivia europea. 
PLATE IV. (1-3, Scale A, others on smaller scale.)

Fig. 1.-Young Trivia ready to metamorphose, 1.44 mm. across shell.

Fig. 2.-Unknown Echinospira, probably Velutina, ready to metamorphose, 1.92 mm. across shell.

Frg. 3.-Echinospira of Lamellaria perspicua ready to metamorphose, $2 \cdot 24 \mathrm{~mm}$. across shell.

Frg. 4.-Adult Trivia.

Frgs. 5, 6.-Adult Trivia eating Diplosoma. 


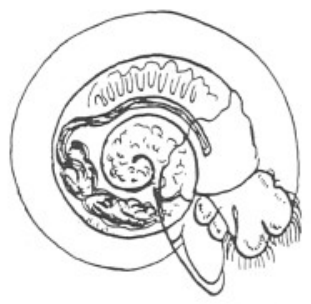

1

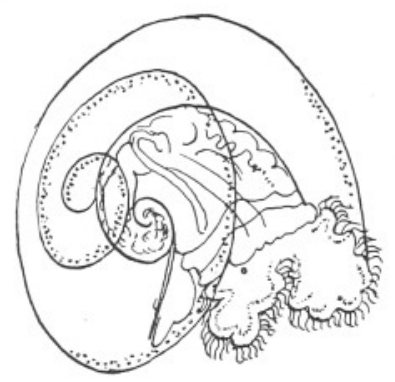

2

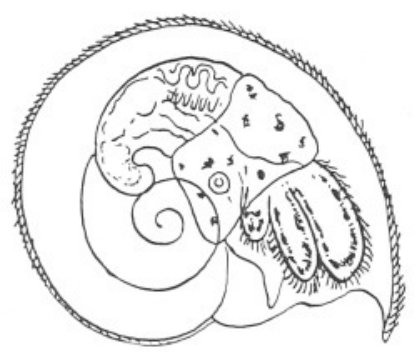

3

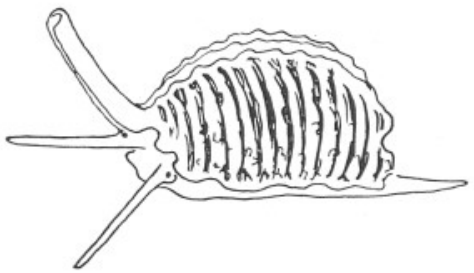

4

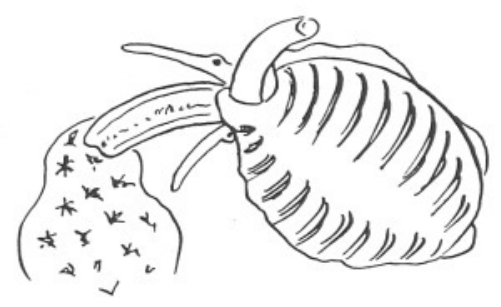

5

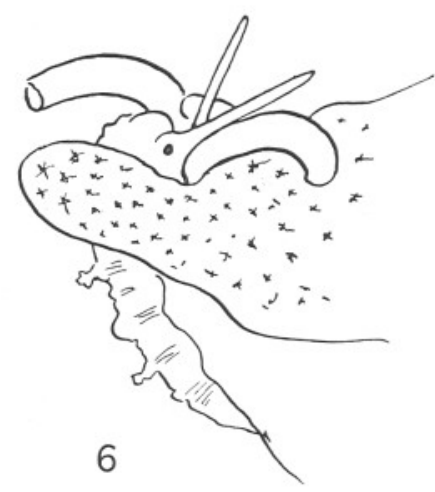

Late larvæ of Trivia, Velutina (?) and Lamellaria. Adult Trivia. 
